\title{
TAKYĪF FIQH PEMBAYARAN JASA TRANSPORTASI ONLINE MENGGUNAKAN UANG ELEKTRONIK (GO-PAY DAN OVO)
}

\section{Hendra Wijaya}

\author{
Sekolah Tinggi Ilmu Islam dan Bahasa Arab (STIBA) Makassar, \\ Jl. Inspeksi PAM Manggala-Antang Makassar \\ Email : abumuslimhwj@gmail.com
}

\begin{tabular}{|c|c|}
\hline Keywords : & $A B S T R A C T$ \\
\hline $\begin{array}{l}\text { electronic money, Go-Pay, } \\
\text { OVO }\end{array}$ & $\begin{array}{l}\text { This research explains differences of opinion among muamalah } \\
\text { experts contemporary about takyiffiqh (deriving law) of transactions } \\
\text { in the use of Go-pay and OVO as a means of payment (electronic } \\
\text { money) on online transportation services, where there are at least four } \\
\text { disputed takyifs, namely al-ijarah al- Mausüfah Fi al-Zimmah, } \\
\text { Wadiah, Qard, and sarf. The differences of takyif figh bas } \\
\text { implications for the differences of law consequences between legal and } \\
\text { illegal transactions in using Go-pay and OVO, this research } \\
\text { explained that it is more effective to derive the law according to the } \\
\text { Sarf contract that is more appropriate than the other contracts, the } \\
\text { substance of Go-pay and OVO top up process is the conversion of } \\
\text { two similar currency between paper money to electric money. Because } \\
\text { Sarf contract is the most appropriate form of contract in this } \\
\text { transaction, the discount acquired by the consumer from the Go-Pay } \\
\text { and OVO payment is considered ataya (gift) that is legal without } \\
\text { any usury. }\end{array}$ \\
\hline
\end{tabular}




\section{PENDAHULUAN}

Manusia adalah makhluk Allah yang utama, Manusia diciptakan dengan sebaik-baik penciptaan QS. alTìn/95:41. Manusia dibekali dengan sifat dan karesteristik tertentu yang dengannya ia mampu menjalankan tanggung jawab kekhalifaan dimuka bumi ini. Diantara karakteristik dasar manusia adalah sebagai makhluk dinamis, yang berarti memiliki sifat penuh semangat, terus bergerak, untuk menghasilkan perubahan dan kemajuan, manusia yang dinamis akan selalu aktif mengikuti perkembangan zaman, sehingga menjadikan ia mampu beradaptasi, berkomunikasi, berintegrasi, bersosilisasi dan berinovasi.

Diantara inovasi manusia yang terus berkembang hingga hari ini adalah penggunaan alat tukar dalam transaksi jual beli. Tahap demi tahap telah dilalui oleh manusia hingga mengenal uang kertas seperti yang kita gunakan hari ini, mulai dari sistem barter, menggunakan alat tukar dari barang-barang yang berharga, koin dari emas ataupun perak, hingga pada zaman menggunakan uang kertas sebagai alat tukar. Perkembangan teknologi yang pesat memaksa manusia terus berinovasi hingga menemukan cara baru yang jauh lebih mudah dan praktis yaitu dengan menggunakan elektronik money atau uang elektronik, saat ini uang elektronik sudah menjadi alat pembayaran yang sah dibeberapa negara, dimana nilai uangnya tersimpan dalam media elektronik. Sejak diterbitkan izin uang elektronik oleh Bank Indonesia melalui Peraturan Bank Indonesia Nomor:

${ }^{1}$ Kementrian Agama, Al-Qur'an dan Terjemahya (Depok; Sabiq 2012), h.597.
11/12/PBI/2009, uang elektronik terus berkembang, hingga hampir seluruh perbankan besar di Indonesia saat ini telah memiliki layanan uang elektronik.

Seakan tidak mau ketinggalan, perusahan jasa transfortasi online yang mulai menjamur sejak tahun 2015 juga menjadikan uang elektronik sebagai pilihan pembayaran dalam transaksinya, seperti gopay pada perusahaan Gojek dan OVO pada perusahaan Grab. Selain alasan mudah dan praktis, pembayaran menggunakan uang elektronik cukup digemari masyarakat Indonesia karena lebih murah dibanding pembayaran tunai, diskonnya berkisar 10rb sampai 20rb dari tarif normal. Perbedaan harga pembayaran menggunakan uang tunai dengan uang elektronik ini yang mennyebabkan polemik antara pakar muamalah syariah. Sebagian menyatakan diskon tersebut adalah riba yang berkonsekuensi pada keharaman, sebab merupakan fäidah (tambahan manfaat) dari aqad qard pinjaman, sedangkan kaidah fikih menyatakan:

\section{كلُ قََْْضِ جَرَّ مَنْفَعَة فَهُوَ رِبًا 2}

Artinya:

"Setiap piutang (pinjaman) yang mendatangkan kemanfaatan (keuntungan), maka itu adalah riba."

Sebagian lain menganggap tidak ada unsur riba di dalamnya karena akadnya bukan qard melainkan salah satu bentuk akad ijārah (sewa menyewa), yang dikenal dengan istilah al-ijārah almausūfah fi al-żimmah sehingga diskon dapat dikategorikan sebagai ataya (pemberian) yang hukum asalnya adalah boleh.

\footnotetext{
2 Muhammad Mușțafā al-Zuhaili, alQawāid al-Fiqhiyah wa Tațbiqātuha fi alMażāhib al-Arba' (Dimasyq: Dār al-Fikr, 1949 H), h.654.
} 
Selain akad qard dan al-iiārah al-mausūfah fi al-zimmah, terdapat pula takyif fiqh (adaptasi fikih) yang lain yaitu akad wadiah dan akad sarf, keduanya berkonsekuensi hukum bolehnya menerima ataya dari perusahaan penyedia jasa transportasi online. Oleh karena itu, melalui makalah ini penulis berupanya mengkajilebih dalam takyif fiqh yang paling sesuai dengan transaksi menggunakan uang elektronik di perusahan jasa transportasi online, khususnya pada saat top up (pengisian saldo) pada aplikasi uang elektronik gopay dan OVO, sehingga diharapkan dapat mengeluarkan hukum fikih yang paling sesuai dengan subtansi masalahnya.

Adapun rumusan masalah dalam penelitian ini adalah bagaimana takyif fiqih pembayaran jasa transportasi online menggunakan uang elektronik (Go-pay dan OVO)? dengan sub masalah:

1. Bagaimanakah sistem transaksi uang elektronik pada transportasi online?

2. Apa saja takyif fiqh pada pembayaran jasa transportasi online menggunakan uang elektronik?

3. Takyif fiqh yang manakah yang paling rajih (kuat)?

\section{PEMBAHASAN}

\section{A. Sistem transaksi uang elektronik pada ojek online}

1. Pengertian Uang Elektronik

Uang elektronik adalah tejemahan bahasa inggris dari elektronik money (e-money), Uang elektronik menurut Bank for International Settlement (BIS) didefinisikan sebagai:

Stored-value or prepaid products in which a record if the funds or value available to a consumer is stored on an electronic device in the consumer's possession ${ }^{3}$

Artinya:

"Produk stored value atau prepaid dimana sejumlah nilai uang disimpan dalam suatu media elektronis yang dimiliki seseorang"

Secara yuridis pengertian uang elektronik diatur pada Peraturan Bank Indonesia terbaru No.20/6/PBI/2018 dalam Bab 1 ketentuan Umum, Pasal 1 angka 3, sebagai berikut:

Uang Elektronik adalah instrumen pembayaran yang memenuhi unsur sebagai berikut: a. Diterbitkan atas dasar nilai uang yang disetor terlebih dahulu kepada penerbit;

b. Nilai uang disimpan secara elektronik dalam suatu media server atau chip; dan

c. Nilai uang elektronik yang dikelola oleh penerbit bukan merupakan simpanan sebagaimana dimaksud dalam Undang-Undang yang mengatur mengenai perbankan. ${ }^{4}$

Dari pengertian diatas dapat disimpulkan bahwa uang elektronik merupakan uang yang berbentuk elektronik memiliki nilai sama layaknya uang tunai, yang diterbitkan oleh penerbit yang telah memiliki izin oleh Bank Indonesia, nilai uang tersimpan secara elektronik dalam suatu media elektronik berupa kartu chip ataupun dalam server setelah melakukan proses

\footnotetext{
3 Bank for International Settlements, Implications for Central Banks of the Development of Electronic Money (Bank For International Settlements 1996).

${ }^{4}$ Bank Indonesia, Peraturan Bank Indonesia Nomor No20/06/PBI/2018, Pasal 1 Angka 3
} 
top up (pengisian saldo), kemudian uang elektronik tersebut berfungsi sebagai alat pembayaran non tunai kepada pedagang atau penyedia barang dan jasa, nilai uang elektronik bukan simpanan sebagaimana dimaksud dalam undang-undang yang mengatur mengenai perbankan, sehingga tidak diberikan bunga dan tidak dijamin oleh Lembaga Penjamin Simpanan (LPS).

2. Perbedaan Uang Elektronik dengan Alat Pembayaran Menggunakan Kartu

Sebelum berlakunya Peraturan Bank Indonesia Nomor 11/11/PBI/2009 dan Peraturan Bank Indonesia Nomor 11/12/PBI/2009, Bank Indonesia masih menggolongkan Uang Elektronik sebagai salah satu Alat Pembayaran Menggunakan Kartu (APMK), seperti Ajungan Tunai Mandiri (ATM), Kartu Kredit dan Kartu Debit. Sejak berlakunya kebijakan baru tahun 2009 maka uang elektronik memiliki karakteristik berbeda dengan APMK, diantara perbedaan mendasar adalah uang elektronik bersifat prepaid (prabayar) sedangkan APMK bersifat akses, dengan uraian sebagai berikut;

a. Nilai uang elektronik tercatat dalam instrumen media uang elektronik, sedangkan dalam APMK tidak tercatat pada instrument kartu

b. Dana pada uang elektronik sepenuhnya berada dalam penguasaan pemegangnya sedangkan dalam APMK dana sepenuhnya berada dalam penguasaan bank.

c. Transaksi pembayaran dapat dilakukan secara off line ke penerbit.Transaksi pembayaran dilakukan secara on line ke penerbit. ${ }^{5}$

3. Jenis-jenis Uang Elektronik

Uang elektonik yang beredar dipasaran tidak hanya dalam satu bentuk saja, namun memiliki banyak varian sesuai dengan jenis dan fungsinya. Jika dilihat dari pencatatan identitas pemegang kartu, maka uang elektronik dapat dibedakan menjadi registered dan unregistered, disebut registered karena data identitas pemegang uang elektronik tercatat atau terdaftar pada penerbit uang elektronik, dan disebut unregistered jika data pemegangnya tidak tercatat pada penerbit uang elektronik. Bank Indonesia kemudian membatasi maksimum dana yang terdapat pada uang elektronik registered sebanyak 5 (lima) juta rupiah, sedangkan pada uang elektronik registered batas maksimumnya sebanyak 1 (satu) juta rupiah. ${ }^{6}$

Berdasarkan media penyimpan nilai uang elektronik, dibedakan menjadi dua yaitu uang elektronik server based dan uang elektronik chip based. ${ }^{7}$ Berdasarkan masa berlakunya, uang elektronik dapat dibedakan menjadi dua, yaitu reloadable dan disposable, disebut reloadable karena uang elektronik jenis ini dapat dikakukan pengisian ulang saldo ketika nilai uang elektroniknya sudah habis terpakai, sedangkan jenis reloadable tidak dapat dilakukan pengisian ulang. ${ }^{8}$

\footnotetext{
${ }^{5}$ Siti Hidayati, dkk, Operasional EMoney (Jakarta: Bank Indonesia 2006) h.4.

6 Bank Indonesia, Peraturan Bank Indonesia Nomor No20/06/PBI/2018, Pasal 3 Angka 2 Huruf b

7 Bank Indonesia, Peraturan Bank Indonesia Nomor No20/06/PBI/2018, Pasal 3 Angka 2 Huruf a

8 Bank Indonesia. Surat edaran Bank Indonesia Nomor 11/11/DASP tentang uang elektronik.
} 
Berdasarkan jangkauan penggunaannya uang elektronik dapat dibedakan menjadi dua bentuk yaitu single-purpose dan multi purpose, singlepurpose adalah uang elektronik yang hanya dapat digunakan pada satu jenis transaksi ekonomi saja, sedangkan multi purpose dapat digunakan untuk berbagai jenis transaksi ekonomi. ${ }^{9}$ Berdasarkan ruang lingkup penggunaannya uang elektronik juga dapat dibedakan menjadi dua, yaitu open loop dan close loop, jika dalam penggunaan uang elektronik ini hanya sebagai instrument pembayaran ditempat penerbit saja disebut close loop, sedangkan jika instrument pembayaran dapat digunakan lebih luas, tidak hanya pada penerbit namun terbuka juga pada berbagai penyedia barang dan jasa maka uang elektronik model ini disebut open loop. ${ }^{10}$

a. Uang elektronik pada aplikasi transportasi online

Dengan bermodal smart phone yang terkoneksi internet, seseorang dapat menikmati layanan transportasi online dengan berbagai fitur yang ditawarkan, pembayarannya pun dapat dilakukan menggunakan berbasis server. Ada dua produk uang elektronik yang saling berkompetisi merebut pasar di Indonesia yaitu Gopay untuk perusahaan Gojek dan OVO untuk Grab, dengan uraian sebagai berikut;

1. Go-pay

Gojek menamakan fitur uang elektroniknya dengan Go-pay,

9 Veithzal Rivai, Andria Permata Veithzal, Ferry N. Idroes., Bank and financial institution management (Jakarta: Raja Grafindo Persada , 2007) h.1367.

10 Bank Indonesia, Peraturan Bank Indonesia Nomor No20/06/PBI/2018, Pasal 3 Angka 1 Huruf a sebagaimana dijelaskan pada website resminya:

"Go-pay adalah uang elektronik yang diterbitkan oleh PT DAB yang terdaftar dan dimonitor oleh Bank Indonesia, yang memiliki fungsi yang sama dengan uang tunai yang dapat digunakan sebagai alat pembayaran yang sah, yang nilainya sama dengan nilai uang tunai yang didepositkan terlebih dahulu di dalam Akun Go-pay,. ${ }^{11}$

Berikut ini layanan yang disiapkan pada fitur Go-pay:

a. Top-Up

Top-Up adalah layanan pengisian saldo akun Go-pay yang dapat dilakukan melalui pengemudi Go-jek, dapat pula dengan cara mentransfer dana melalui bank-bank tertentu di Indonesia atau melalui institusi atau platform lain yang ditentukan

b. Pembayaran.

Go-pay dapat digunakan untuk membayar tagihan transaksi kepada pelaku usaha yang menawarkan layanannya. Setiap Pembayaran akan secara otomatis mengurangi saldo Go-pay dengan jumlah dan nominal yang sama.

c. Transfer Dana

Transfer dana merupakan layanan untuk mengalihkan dana ke akun Go-pay lainnya yang akan secara otomatis mengurangi saldo yang tertera dalam akun Go-pay asal dan menambah saldo akun Go-pay pihak lain dengan jumlah yang sama.

d. Penarikan Tunai

\footnotetext{
${ }^{11 G o j e k ~ I n d o n e s i a, ~ " K e b i j a k a n ~ P r i v a s i ~}$ Gopay"Situs Resmi Gojek. https://www.gojek.com/go-pay/kebijakan-privasi/ (22 Februari 2018).
} 
Penarikan Tunai merupakan layanan untuk menarik dana yang terdapat dalam akun Go-pay melalui bank yang telah terdaftar, yang akan secara otomatis mengurangi saldo Go-pay dengan jumlah yang sama ${ }^{12}$

\section{OVO}

Sebagai kompetitor utama

Gojek dalam bisnis transportasi online, Grab juga tidak mau ketinggalan menyiapkan fitur pembayaran non tunai yang diberi nama Saldo OVO, sebelumnya disebut Grabpay lalu kemudian berevolusi menjadi OVO setelah grab bekerja sama dengan PT Visionet Internasional, layanan saldo OVO yang dioperasikan oleh PT Visionet Internasional ini telah memperoleh izin dari Bank Indonesia sebagai penerbit uang elektronik. ${ }^{13}$

Fitur dan layanan Saldo OVO umumnya sama dengan Gopay, saldo OVO dapat digunakan sebagai pembayaran non tunai pada layanan yang disiapkan oleh Grab seperti Grabcar, Grabbike, GrabFood, GrabExpress dll, layanan OVO juga dapat digunakan untuk pembayaran pada layanan merchant (pihak ketiga) yang telah ditentukan oleh Grab dan OVO, disamping itu layanan transfer saldo ke akun lain sudah dapat dilakukan termasuk transfer ke rekening bank apabila dengan syarat telah mengupgre menjadi OVO Primer. Saldo OVO tidak memiliki

12 Gojek Indonesia, "Kebijakan Privasi Gopay"Situs Resmi Gojek. https://www.gojek.com/go-pay/kebijakan-privasi/ (22 Februari 2018).

$\begin{array}{lrr}{ }^{13 G r a b} & \text { Indonesia, } & \text { "Ketentuan } \\ \text { layanan"Situs } & \text { Resmi } & \text { Grab. } \\ \text { https://www.grab.com/id/terms/ } & \text { (230ktober } \\ \text { 2018) } & \end{array}$

masa kadaluarsa, dapat berlaku seumur hidup. ${ }^{14}$

3. Komparasi antara Gopay dengan OVO

Mekanisme kerja pada aplikasi uang elektronik Go-pay dan OVO tidak jauh berbeda, sehingga didapati banyak persamaan antara keduanya diantara persamaannya adalah keduanya menawarkan dua pilihan tarif dalam satu waktu, yaitu tarif normal dengan pembayaran tunai dan tarif diskon dengan pembayaran menggunakan uang elektronik. Konsumen diberi kebebasan memilih antara dua pilihan sistem pembayaran tersebut, contoh kasus pak Eko ingin memesan jasa trnasportasi taksi on line dari kampus STIBA Makassar menuju Bandara Sultan Hasanuddin pada hari Rabu 26 Desember 2018, pukul 12.30 WIB, maka pak Eko memulai dengan mengecek tarif transportasi online pada aplikasi yang telah diinstall sebelumnya pada smart phone miliknya, sehingga pak Eko mendapat penawaran tarif dari Gojek seharga Rp. 71.000,- untuk pembayaran tunai dan Rp. 57.000,- untuk pembayaran menggunakan Go-pay, selisih tarif antara kedua metode pembayaran ini sebanyak Rp. 14.000,- atau 19,72\%. Pada aplikasi Grab menawarkan tarif Rp. 72.000,- untuk pembayaran tunai, dan Rp. 70.000,- untuk pembayaran menggunakan OVO dengan selisih tarif antara keduanya sebanyak Rp. 2.000,- atau 2,78\% , untuk lebih jelasnya dapat digambarkan pada tabel berikut ini:

\begin{tabular}{|l|l|ll|}
\hline Perusahan & Uang & Rute Perjalanan/ Waktu \\
Transportasi & Elektronik & Pemesanan & \\
\hline
\end{tabular}

\begin{tabular}{lcr}
\hline${ }^{14}$ Grab & Indonesia,"OVO & dan \\
Pembayaran" & Situs Resmi & Grab \\
https://help.grab.com/hc/id/115001982507- & \\
OVO-dan-Pembayaran?launch_path=N\%2FA (23 \\
Oktober 2018)
\end{tabular}




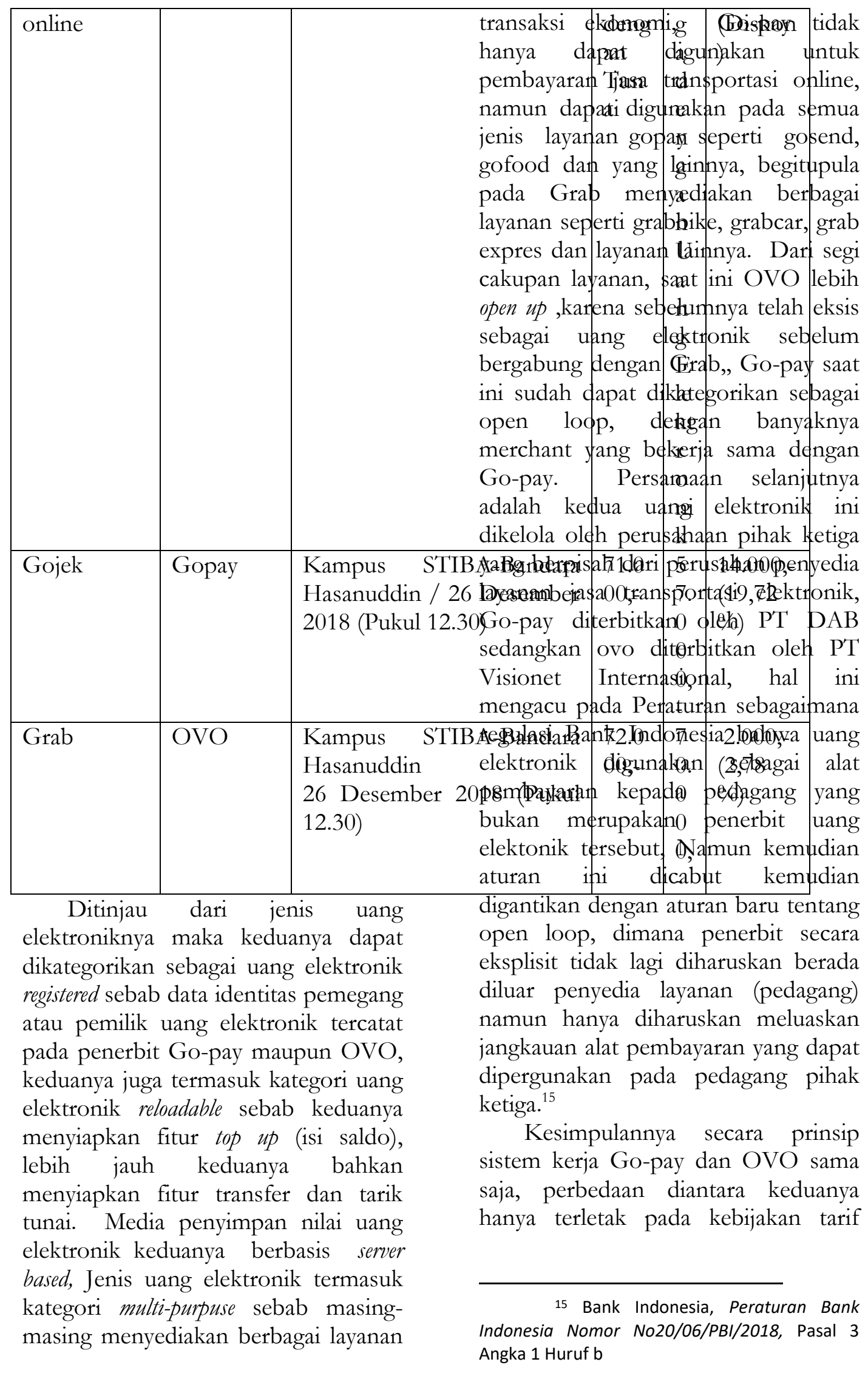


transportasi yang dikeluarkan oleh pihak penyelenggara jasa transportasi.

\section{B. Takyïf fiqh pembayaran jasa transportasi online menggunakan uang elektronik}

Tidak ada perbedaan pendapat dikalangan ulama bahwa pembayaran jasa transportasi online seperti Gojek dan Grab yang dilakukan menggunakan uang tunai adalah merupakan akad ijärah (sewamenyewa), dimana konsumen membayar jasa tumpangan transportasi sesuai tarif yang disepakati, hal ini sejalan dengan makna ijärah secara istilah berupa:

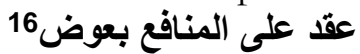

Artinya:

"Akad atas hak guna (manfaat) dengan pembayaran upah"

Yang menjadi polemik dikalangan pakar muamalah kontemporer adalah pembayaran dengan menggunakan uang elektronik seperti Go-Pay dan OVO, dimana tarif jasa menggunakan uang elektronik dipastikan lebih murah dari pada pembayaran dengan uang tunai, pembayaran menggunakan uang elektronik mendapatkan diskon sedangkan pembayaran tunai dengan uang kertas dengan tarif normal (tanpa diskon), Inti masalahnya adalah apakah diskon yag didapatkan termasuk riba atau tidak? Hal ini menjadi polemik karena konsumen sebelum menggunakan uang elektronik tersebut, terlebih dahulu melakukan proses top up yaitu pengisian saldo dengan uang tunai dengan nilai tertentu, saldo inilah yang akan tersipan sampai konsumen menggunakannya, dan akan berkurang sesuai pemakaian, sebagian menyatakan bahwa proses top up (isi

${ }^{16}$ Sayyid Sābiq, Fiqh al-Sunnah (Bairūt: Muassasah al-Rayyan, 2002) h.850. saldo) subtansinya adalah qard (pinjaman) sehingga tidak dibenarkan menerima manfaat berupa diskon, sebab manfaat berkonsekuensi pada perbuatan riba yang diharamkan, sebagian yang lainnya berpendapat berbeda dan tidak mengkategorikan proses top up sebagai akad qard.

Karena transaksi menggunakan uang elektronik pada transportasi online tersebut termasuk perkara kontemporer maka dipandang perlu untuk melakukan takyif fiqh atau adaptasi fikih sebagai upaya pendekatan fikih terhadap akad-akad yang telah dikenal sebelumnya dalam muamalah, sehingga pilihan hukum terhadap transaksi tersebut lebih mendekati kebenaran. Sebagaimana kaidah yang terkenal dikalangan ulama empat mazhab ${ }^{17}$ :

Artinya:

$$
\text { الحكم على الثيء فرع عن تصوره }
$$

"Hukum terhadap suatu kasus, adalah turunan dari bagaimana seseorang melihatnya"

Paling kurang terdapat empat kemungkinan takyif fikih pada model transaksi ini, yaitu al-ijärah al-mausüfah fi al-żimmah, Wadiah, Qarḍ, dan Șarf, dengan uraian sebagai berikut;

1. Al-Ijärah al-Mausūfah fi alZimmah

Diantara bentuk ijārah yang banyak ditemukan pada akad muamalah kontemporer adalah akad ijärah dalam bentuk bai' salam (Jual-beli pesanan), akad semacam ini lebih dikenal dengan istilah al-ijärah almausūfah fi al-zimmah, Dewan Syariah Nasional Majelis Uama Indonesia (DSN-MUI) mendefenisikan akad ini sebagai berikut:

17 Ahmad bin Abdu al-Halīm bin Taimiyah, Majmū' al-Fatāwa (Al-Madinah alMunawwarah:), h.295. 
"Akad sewa menyewa atas manfaat suatu barang (manfaat ain) dan/atau jasa ('amal) yang pada saat akad hanya disebutkan sifatnya dan spesifikasinya (kuantitas dan kualitas)" ${ }^{\prime 18}$

Akad al-ijärah al-mausüfah fi alżimmah juga diterangkan dalam standar Internasional Accounting And Auditing Organization For Islamic Financial Institutions (AAOFI) :

$$
\begin{aligned}
& \text { يجوز أن تقع الإجارة على موصوف في الذمّة وصفا منضبطا } \\
& \text { ولو لم يكن مملوكا للمؤجّر (الإجارة الموصوفة في الذمة تونة } \\
& \text { حيث يتّقق على تسليم العين الموصوفة في موعد سريان } \\
& \text { العقد. ويراعى في ذلك إمكان تملّك المؤحر لها أو صنعها. }
\end{aligned}
$$

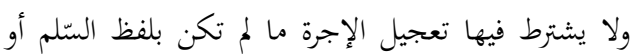

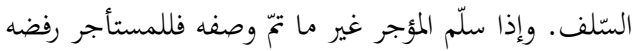

$$
\begin{aligned}
& \text { وطلب ما تتحقّق فيه المواصفات } 19 .
\end{aligned}
$$

Artinya:

Dibolehkan Akad al-ijärah almausüfah fi al-ìimmah yang dilakukan dengan syarat kriteria barang sewa terukur meskipun obyek sewa tersebut belum menjadi milik pemberi sewa (pada saat akad). Waktu penyerahan barang sewa disepakati pada saat akad, barang sewa tersebut harus diyakini dapat menjadi milik pemberi sewa baik dengan cara memperolehnya dari pihak lain maupun membuatnya sendiri. Tidak dipersyaratkan pembayaran upah didahulukan (dilakukan pada saat akad) selama ijab-qabul yang dilakukan tidak menggunakan

18 Dewan Syariah Nasional Majelis Ulama Indonesia, Fatwa Nomor 102/DSNMUI/X/2016 tentang akad Al-ljārah al-Mausufah fi al-Dzimmah Untuk Produk Pembiayaan Pemilikan Rumah (PPR)-Inden, h.7.

19 Haiah al-Muhāsibah wa al-Murāja'ah Li al-Muassasāt al-Māliyah al-Islāmiyah, AlMa'āyīru al-Syari'ah (Al-Bahrain: Dār al-Maimān Li al-Nasyar wa al-Tauzī', 1437 H) h.243. kata salam atau salaf. Aapabila barang sewa diterima penyewa tidak sesuai dengan kriteria yang disepakati, pihak penyewa berhak menolak dan meminta gantinya yang sesuai dengan kriteria yang disepakati pada saat akad.

Sebagian pakar muamalah menggolongkan akad Go-pay maupun OVO sebagai akad al-ijärah al-mausüfah fi al-zimmah, diantaranya Dr. Oni Sahroni, MA. ${ }^{20}$, dengan argumentasi bahwa pembayaran ijärah dibayar dimuka, manfaat diterima kemudian, akad semacam ini adalah bagian dari akad salam yang dibolehkan dalam syariat, Dr. Oni Sahroni, MA menyimpulkan skema akadnya sebagai berikut:

a. Substansi transaksinya adalah jual beli jasa untuk manfaat yang akan diserah terimakan dengan discount tertentu bagi pengguna.

b. Substansinya bukan utang / pinjaman, tetapi jual beli jasa. Deposit itu sebagai upah yang dibayarkan di muka. Juga customer tidak bermuamalah dengan bank tetapi dengan pihak gojek layaknya e money.

c. Dengan demikian, maka skema Ijārah maushufah fi dzimmah lebih tepat digunakan untuk aplikasi ini : ujrah (fee) dibayar dimuka, manfaat dibayar kemudian.

d. Karena akadnya al-ijärab almaușūfah fi al-ìimmah, menjadi

20 Dr. Oni Sahroni, MA, sebagai Direktur SEBI Islamic Business \& Economics Research Center (SIBER-C), Anggota Dewan Syariah Nasional (DSN) MUI, Tim Ahli Syariah ISRA - Bank Negara Malaysia, dan Anggota Dewan Standar Akuntansi Syariah (DSAS) IAI, http://www.rumahwasathia.org/rumahwasathia /biografi (7 Januari 2019) 
Website: https://journal.stiba.ac.id

ISSN : 2685-7537 (online) 2338-5251 (Printed)

hak pihak yang menyewakan jasa (muajjir / gojek) untuk memberikan discount sebagai athaya dan pemberian yang dibolehkan oleh syara. ${ }^{21}$

Sejalan dengan argumentasi diatas, Ammi Nur Baits, ST., BA. ${ }^{22}$ pada awalnya berpendapat bahwa akad pada gopay adalah ijärah, alasannya saldo Go-pay tidak bisa diuangkan, sebagaimana aturan awal Go-pay, karena saldo tidak bisa diuangkan maka subtansi akadnya adalah ijärah bukan utang, sebab hanya utang yang wajib dikembalikan dengan uang, namun pendapat ini kemudian direvisi dengan setelah munculnya fitur tarik tunai pada Gopay. ${ }^{23}$

Adanya fitur tarik tunai tidak serta merta mengalihkan akad ijärah menjadi akad qard, sebagaimana dikemukakan oleh Ronny mahmuddin, Lc., M.A. ${ }^{24}$ dalam Liqa 'Ilmi 19 Dewan Syariah Wahdah Islamiyah bahwa tarik tunai dapat dikategorikan sebagai iqālah yaitu pembatalan akad, sehingga fitur tarik

${ }^{21}$ Rumah Wasatia, "Tanya Jawab Fikih Muamalah No. 501 Hukum Top Up dalam Jasa Transportasi Online", Blagspot Rumah Wasatia http://rumahwasatia.blogspot.com/2017/10/tan ya-jawab-fikih-muamalah-no-501-hukum.html (7 Januari 2019).

${ }^{22} \mathrm{Ammi}$ Nur Baits, ST., BA. Salah seorang dewan pembina konsultasi syariah pada situs konsultasisyariah.com , "about" https://konsultasisyariah.com/about (7 Januari 2019)

${ }^{23}$ Sang Pendoa, "Hukum Go Pay Dalam Pandangan Islam I Takyif Fiqih I Ust Ammi Nur Baits" https://www.youtube.com/watch?v=h2T2vK789E\&t=908s (23 Oktober 2018)

${ }^{24}$ Ronny mahmuddin, LC., M.A. adalah Ketua Divisi Ibadah Dewan Syariah Wahdah Islamiyah Priode 2016-2021, Wahdah Islamiyah, "Susunan Pengurus Dewan Syariah Wahdah Islamiyah" http://wahdah.or.id/susunanpengurus-dewan-syariah-wahdah-islamiyah/ (7 Januari 2019) tunai pada gopay adalah iqālah (pembatalan) dari akad ijarah ${ }^{25}$

Konsekuensi hukum dari akad al-ijärah al-mausūfah fi al-izimmah adalah bolehnya bertransaksi dengan uang elektronik (Go-Pay dan OVO) karena tidak ada unsur riba didalamnya, adapun diskon khusus pada pembayaran non tunai menggunakan uang elektronik bukanlah manfaat dari hutang-piutang (riba), sebab menjadi hak pihak yang menyewakan jasa (Gojek dan Grab) untuk memberikan diskon sebagai athaya (pemberian) yang dibolehkan dalam syariat.

2. Wadiah

Barang titipan dalam muamalah dikenal dengan istilah wadiah, kata wadiah berasal dari kata wadaa' syai (menyimpan sesuatu) atau taraka syai (meninggalkan sesuatu), Barang titipan dinamakan wadiah karena sesuatu (barang) tersebut ditinggalkan disisi orang yang dititipinya. ${ }^{26}$

Proses top up pada aplikasi Go-pay maupun OVO dapat ditakyif sebagai proses penitipan uang atau wadiah, uang titipan nantinya akan digunakan untuk keperluan pembayaran jasa transportasi, Menurut Dzulqarnain bin Muhammad Sunusi ${ }^{27}$ dalam video youtobe menjelaskan bahwa seseorang yang perlu jasa akan menitipkan uangnya pada gopay sehingga dengan mudah membayarnya, sehingga tidak tepat jika dikatakan bahwa konsumen meminjamkan uang ke pihak gopay, menurutnya pendapat tersebut

${ }^{25}$ Dewan Syariah Wahdah Islamiyah, Resume Liqa' IImi 19 Dewan Syariah (Makassar: tp, 2018)

26Sayyid Sabiq, Fiqhu al-Sunnah, h.873.
27 Dzulqarnain bin Muhammad Sunusi
sebagai pembina di Ma'had As-Sunnah
Makassar, Dzulqarnain $\quad$ "Biografi"
http://dzulqarnain.net/biografi (8 Januari 2019)

${ }^{26}$ Sayyid Sabiq, Fiqhu al-Sunnah, h.873. http://dzulqarnain.net/biografi (8 Januari 2019)

Hendra Wijaya. Takyif Fiqh Pembayaran ... 
Website: https://journal.stiba.ac.id

ISSN : 2685-7537 (online) 2338-5251 (Printed)

termasuk memaksakan hukum, sebab pada hakikatnya top up adalah menitipkan uang bukan meminjamkan uang. ${ }^{28}$

Sejalan dengan pendapat ini, Islahuddin Mubarak, Lc.,M.H ${ }^{29}$, dalam Liqa 'Ilmi 19 Dewan Syariah Wahdah Islamiyah berpandangan bahwa dalam transaksi menggunakan Go-pay terdapat dua akad yang terjadi secara terpisah yaitu akad wadiah dan akad ijärah, ketika konsumen melakukan top up (mengisi saldo) maka saat itu subtansinya aadalah akad wadiah, kemudian ketika konsumen menggunakan jasa barulah transaksi ijārah terjadi. ${ }^{30}$

Karena pengisian saldo adalah wadiah dan selama penitipan uang tersebut tidak ada bunga (penambahan saldo) maka konsekuensi hukumnya transaksi tersebut boleh dan tidak riba, diskon yang didapatkan berupa atayah (hadiah) dari pihak penyedia jasa kepada konsumen.

\section{Qard}

Pinjaman dalam muamalah disebut qard, secara bahasa qard maknanya al qata' (memotong) , dikatakan demikian sebab pemberi hutang ketika ia meminjamkan uangnya ibaratnya memotong sebagian dari harta miliknya, diantara definisi qardh secara istilah adalah:

${ }^{28}$ Media Berdakwah, "Hukum Go Food dan Go Pay - Fadhilatul Ustadz Dzulqarnain M Sunusi"

https://www.youtube.com/watch?v=GJWvLr8po Ck (23 Oktober 2018)

${ }^{29}$ Islahuddin Mubarak, Lc.,M.H. adalah Sekretaris Divisi Muamalat Dewan Syariah Wahdah Islamiyah Priode 2016-2021, Wahdah Islamiyah, "Susunan Pengurus Dewan Syariah Wahdah Islamiyah" http://wahdah.or.id/susunan-pengurus-dewansyariah-wahdah-islamiyah/ (7 Januari 2019)

30 Dewan Syariah Wahdah Islamiyah, Resume Liqa' Ilmi 19 Dewan Syariah

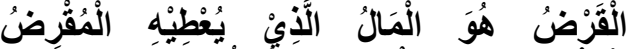

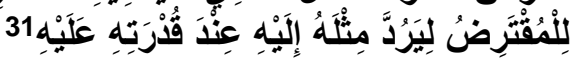

Artinya:

Al-qarḍh adalah harta yang diberikan oleh pemberi utang (muqrid) kepada penerima utang (muqtarid) untuk kemudian dikembalikan kepadanya (muqridh) seperti yang diterimanya, ketika ia telah mampu membayarnya.

Proses top up subtansinya adalah qard (pinjaman), sebagaimana apa yang dikemukan oleh Dr. Erwandi Tarmizi Lc.,MA. ${ }^{32}$, menurutnya deposit Go-pay dapat disamakan hukumnya dengan transaksi menitip uang pada toko sembako dekat rumah dengan tujuan dapat diambil barang setiap dibutuhkan, pembayaran harga barang dapat dikurangi langsung dari saldo uang yang telah dititipkan. ${ }^{33}$ Untuk mendukung pendapat ini Dr. Erwandi Tarmizi Lc.,MA. mengutip perkataan Ibnu Abidin tentang bentuk bai' istijrar yang diterjemahkan dalam buku Harta Haram Muamalat Kontemporer sebagai berikut:

Bila seseorang menyerahkan sejumlah uang kepada penjual, setiap harinya dia mengambil barang sebanyak 5 item dan pada saat menyerahkan uang dia tidak mengatakan, "saya beli darimu 5 item setiap harinya...

\footnotetext{
${ }^{31}$ Sayyid Sābiq, Fiqh al-Sunnah, h.840

${ }^{32} \mathrm{Dr}$. Erwandi Tarmizi LC.,MA., penulis buku Harta Haram Muamalat Kontemporer, Dosen tetap di program magister Ekonomi Syariah Sekolah Tinggi Ekonomi Islam Tazkia Bogor, Anggota Dewan Fatwa Perhimpunan AlIrsyad, Pemateri fiqih kontenporer radio rodja, rodja TV bogor. ErwandiTarmizi " $M e^{\text {" }}$ https://erwanditarmizi.com/about/ (8 Januari 2019)

33 Erwandi Tarmizi, Harta Haram Muamalat Kontemporer (Bogor: PT. Berkat Mulia Insani, 2017), h.321
} 
Aku berkata," Hukumnya boleh jika harga 5 item tersebut telah jelas sebelumnya seperti roti dan daging. Adapun jika harganya tidak diketahui pada saat mengambil barang maka akad jual-belinya tidak sah karena harga pada saat transaksi tidak jelas.Maka apabila barang telah digunakan oleh pihak penitip uang dan sungguh penjual telah menyerahkannya dengan ridha dan dengan tujuan mendapat uang maka sesungguhnya akad jual-beli belum terjadi.Walaupun niat kedua belah pihak untuk melakukan akad jual-beli, hal ini dikarenakan akad jual beli tidak sah dengahan niat saja. Maka sesungguhnya yang terjadi hampir serupa dengan akad Qarḍh (dimana penitip uang meminjamkan uangnya dan penjual meminjamkan barangnya) yang dia menjamin uang atau barang dengan semisalnya atau senilainya. ${ }^{34}$

Berdasarkan argumentasi tersebut maka disimpulkan bahwa subtansi akad pada saat top up adalah qard (pinjaman), dimana konsumen sebagai muqrid (pemberi pinjaman) sedangkan penyelenggara Go-Pay (Gojek) muqtarid (penerima pinjaman), sehingga diskon yang diterima mugrid (pemberi pinjaman) dari muqtarid (penerima pinjaman) adalah riba karena setiap manfaat dari pinjaman hukumnya riba, sebagaimana kaidah fikih:

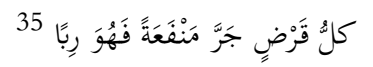

34 Erwandi Tarmizi, Harta Haram Muamalat Kontemporer, h.321-322

35 Muhammad Muștafā al-Zuhaili, alQawāid al-Fiqhiyah wa tațbiqātuha fí al-Mażāhib al-Arba', h.654.
Artinya:

"Setiap piutang (pinjaman) yang mendatangkan kemanfaatan (keuntungan), maka itu adalah riba."

Pendapat ini kemudian diperkuat lagi dengan fatwa yang dikeluarkan oleh Dewan Fatwa Perhimpunan Al Irsyad pada tanggal 1 Maret 2018 di Jakarta, tentang haramnya diskon yang didapatkan dari Go-pay dan layanan yang sejenisnya, dengan kesimpulan:

"Hukum memakai Go-Pay pada asalnya adalah Halal, asalkan tidak memakai atau mendapatkan potongan harga maupun tambahan manfaat lainnya, karena hal itulah yang menjadikannya Riba, Fatwa haramnya pemanfaatan diskon pada Go-Pay juga berlaku pada transaksi pembayaran lainnya seperti pada kartu deposit berfasilitas. ${ }^{36}$

Setelah perubahan aturan Gopay bahwa saldo Go-pay dapat diuangkan kembali, maka Ammi Nur Baits merevisi pendapat sebelumnya dan sependapat bahwa akad transaksi gopay adalah akad utang, dengan alasan bawa jual beli atau ijärah itu harus ditandai dengan akad dan bukan sekedar niat akad, seandainya benar akadnya adalah ijärah, tentu tidak ada fitur tarik kembali saldo. ${ }^{37}$

Karena Akadnya adalah akad qard maka konsekuensi hukum

36 Dewan Fatwa Perhimpunan AlIrsyad, Fatwa Haramnya Diskon yang didapatkan dari Go-pay dan Layanan yang sejenisnya Nomor 005/DFPA/VI/1439, Angka 4 dan 5 Bank Indonesia, Peraturan Bank Indonesia Nomor No20/06/PBI/2018, Pasal 3 Angka 1 Huruf b

37 Sang Pendoa, "Hukum Go Pay Dalam Pandangan Islam I Takyif Fiqih I Ust Ammi Nur Baits" https://www.youtube.com/watch?v=h2T2vK789E\&t=908s (23 Oktober 2018) 
Website: https://journal.stiba.ac.id

ISSN : 2685-7537 (online) 2338-5251 (Printed)

menerima manfaat berupa diskon adalah riba yang diharamkan.

\section{4. Șarf}

Pertukaran uang dalam fikih muamalah disebut akad al sharf, secara bahasa al-ṣarf mempunyai arti $A l$ Ziyadah (tambahan), Sedangkan secara istilah al-șarf adalah:

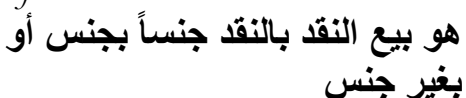

Artinya:

"Pertukaran mata uang dengan mata uang lainya baik satu jenis maupun lain jenis" 38

Pengisian saldo (top up) dapat ditakyif sebagai akad penukaran uang yang sejenis, yaitu pertukaran rupiah dalam bentuk uang kertas dengan uang elektronik. Pendapat ini dikemukaan oleh Asri, Lc., MA ${ }^{39}$ dalam Liqa 'Ilmi 19 Dewan Syariah Wahdah Islamiyah, bahwa terdapat dua jenis akad dalam transaksi Go-pay, akad pertama adalah șarf dimana konsumen menukarkan uang tunai rupiahnya menjadi uang elektronik juga dalam bentuk rupiah, sehingga subtansinya tidak ada wadiah (penitipan) dan tidak ada qard (pinjaman) dalam proses top up, yang ada hanyalah perubahan bentuk dari tunai ke elektronik, kemudian akad kedua adalah ijarah, sehingga walaupun konsumen mendapatkan diskon dari penyedia jasa (Gojek) tidak ada masalah sebab hal tersebut adalah pemberian biasa bukan riba. ${ }^{40}$

38 Wahbah Al-Zuhaili, Al-Fiqh al-Islami wa Adillatuhu (Dimasq: Dar al-Fikr, 1433 H), h.659.

39 Asri, Lc., M.A. adalah Ketua Divisi Muamalat Dewan Syariah Wahdah Islamiyah Priode 2016-2021, Wahdah Islamiyah, "Susunan Pengurus Dewan Syariah Wahdah Islamiyah" http://wahdah.or.id/susunan-pengurus-dewansyariah-wahdah-islamiyah/ (7 Januari 2019)

40 Dewan Syariah Wahdah Islamiyah, Resume Liqa' Ilmi 19 Dewan Syariah
Takyif dengan akad șarf sejalan dengan pandangan Yusuf Bin Abdullah al-Syubaili ${ }^{41}$ tentang hukum menggunakan Saudi Tech, semacam kartu belanja online yang dapat digunakan setelah top up (isi saldo) sejumlah tertentu, kartu ini memiliki nomor rekening terdiri dari 16 angka dan dapat dipergunakan belanja secara online disetiap merchant yang menerima logo Mastercard. Yusuf Bin Abdullah al-Syubaili menjawab bahwa terdapat dua kemungkinan takhyif figh dari kartu tersebut yaitu qard dan șarf, namun menurutnya akad qard jauh dari subtansi, sebab kartu tersebut pada dasarnya memiliki nilai tersendiri, nilai tersebut telah diterima sepenuhnya oleh pemilik kartu dalam bentuk elektronik sehingga tidak tepat dikatakan qard, menurutnya perbedaan pandangan ulama seperti ini pernah terjadi diawal munculnya uang kertas setelah sebelumnya menggunakan logam dari emas dan perak, pada awalnya sebagian fukaha berpedapat bahwa pertukaran logam emas dan perak menjadi uang kertas sebagai qard, namun seiring dengan diterimanya uang kertas ditengahtengah masyarakat sebagai alat tukar yang memiliki nilai maka pendapat inipun tidak lagi menguat. ${ }^{42}$

Karena bentuknya akad șarf maka dua syarat utama dalam akad șarf sudah terpenuhi yaitu kontan dan tidak ada tambahan jika ditukarkan

41 Yusuf Bin Abdullah al-Syubaili sebagai pengajar di al-Ma'had al-'Ali Li al-Qaḍa . Islam Way "Profil Yusuf Albdullah al-Syubaili" https://ar.islamway.net/scholar/325/profile (8 Januari 2019)

42Islam Way "Fatwa mufașșalah fi alBițaqāt al-Madfūah musbiqa" https://ar.islamway.net/fatwa/34033 (8 Januari 2019). 
uangnya sejenis, sehingga transaksi Go-pay dibolehkan dan bukan riba.

\section{Pendapat Yang Rājih (Pilihan)}

Perbedaan pendapat para pakar muamalah disebabkan perbedaan cara pandang terhadap sistem akad yang terjadi pada transaksi menggunakan Go-pay maupun OVO sebagaimana dijelaskan dimuka, dari keempat pendekatan tersebut peneliti berpendapat bahwa takyif figh yang lebih dekat adalah akad șarf dengan alasan:

1. Go-pay dan OVO termasuk uang elektronik resmi yang diterbitkan sesuai regulasi Bank Indonesia, saldo pada Go-pay dan OVO adalah saman (nilai uang) bukan masmün (barang atau jasa), sehingga pertukaran uang dengan uang secara kontan adalah bentuk akad șarf , bukan pengembalian uang yang ditangguhkan seperti wadiah dan qard dan bukan pula pertukaran uang dengan manfaat seperti al-ijärah almausūfah fi al-ìimmah .

2. Ulama sepakat bahwa akad wadiah termasuk akad amanah, sehingga tidak diperkenangkan bagi muwadda' (yang dititipi) untuk

menggunakan/memanfaatkan barang titipan tersebut tanpa seizin muwaddi (pemilik barang), jikalau pemilik barang merelakan barang miliknya dimanfaatkan maka secara otomatis akadnya beralih dari akad wadiah berpindah keakad qard, Sesuai aturan Bank Indonesia bahwa penerbit dapat mengelola dana yang masuk sehingga tidak tepat dikatakan sebagai aqad wadiah.

3. Jika sekiranya proses top up (isi saldo) dikategorikan sebaagai akad qard, Maka tidak serta merta diskon yang diberikan oleh perusahaan jasa transportasi (Gojek dan Grab) dikategorikan sebagai manfaat yang mengandung riba, sebab diskon yang diperoleh konsumen (pemberi pinjaman) bukan dari penerbit (penerima pinjaman) melainkan dari pihak ketiga yaitu dari pedagang dalam hal ini penyedia jasa transportasi online ataupun merchant tertentu yang lainnya, sehingga pemberiannya (diskon) dikategorikan sebagai hadiah yang dibolehkan.

Karena akad sarf dipandang sebagai akad yang paling tepat pada proses top up uang elektronik, maka konsekuensi hukumnya yaitu bolehnya pembayaran jasa transportasi online menggunakan uang elektrinik (Go-pay dan OVO) karena sudah memenuhi syarat dari akad $\dot{s} a r f$ uang sejenis yaitu kontan dan dengan nilai yang sama, adapun diskon yang diberikan oleh perusahaan transportasi online bukanlah termasuk riba melainkan ațaya (hadiah) yang dibolehkan. Namun mengingat uang elektronik terus berkembang secara dinamis dari waktu kewaktu, maka takyif fikih juga akan selalu dinamis mengikuti regulasi dan aturan yang berlaku.

\section{KESIMPULAN}

Dari berbagai pemaparan materi dimuka maka dapat ditarik kesimpulan sebagai berikut: 
1. Transportasi online di Indonesia sudah menyiapkan fitur pembayaran berupa uang elektronik yang berlisensi Bank Indonesia seperti Go-pay dan OVO. Uang elektronik ini merupakan uang yang berbentuk elektronik memiliki nilai sama layaknya uang tunai, yang diterbitkan oleh penerbit setelah melakukan proses top up. kemudian disimpan secara elektronik dalam suatu media elektronik berbasis server, kemudian e-money ini berfungsi sebagai alat pembayaran non tunai.

2. Terdapat perbedaan pendapat para pakar fikih muamalah terhadap hukum menggunakan Go-pay dan OVO atau semacamnya, perbedaan pendapat disebabkan perbedaan cara pandang terhadap sistem akad yang terjadi pada transaksi elektronik tersebut, terdapat paling sedikit empat takyif fikih pada proses top up (isi saldo) pada uang elektronik yaitu alIjärah al-Maushufah fi al-Drimmah, Wadiah, Qard, dan Sharf.

3. Tendapat yang dipilih sebagai takyif fikih yang paling tepat adalah akad sorf, diantara alasannya; (1) saldo pada Go-pay dan OVO adalah saman (nilai uang) bukan masmūn (barang atau jasa), sehingga pertukaran uang dengan uang secara kontan adalah bentuk akad șarf bukan al-ijärah almaushufah fi al-izimmah, wadiah dan bukan Qard, (2) Sesuai aturan Bank Indonesia bahwa penerbit uang elektronik diperbolehkan mengelola dana yang masuk sehingga tidak tepat dikategorikan sebagai wadiah, (3) Jika dikategorikan sebagai akad qard, Maka tidak serta merta diskon yang diberikan oleh perusahaan jasa transportasi (Gojek dan Grab) dikategorikan sebagai manfaat yang mengandung riba, sebab diskon yang diperoleh dari pihak ketiga yaitu dari pedagang (penyedia jasa transportasi online) ataupun merchant tertentu yang lainnya, sehingga pemberiannya (diskon) dikategorikan sebagai hadiah yang dibolehkan.

\section{DAFTAR PUSTAKA}

Bank for International Settlements, Implications for Central Banks of the Development of Electronic Money. Bank For International Settlements 1996.

Haiah al-Muhāsibah wa al-Murāja'ah Li al-Muassasāt al-Māliyah alIslāmiyah, Al-Ma'āyīru alSyari'ah. Al-Bahrain: Dār alMaimān Li al-Nasyar wa alTauzî, $1437 \mathrm{H}$.

Hidayati, Siti dkk. Operasional E-Money. Jakarta: Bank Indonesia 2006.

Kementrian Agama, Al-Qur'an dan Terjemahya. Depok; Sabiq 2012.

Rivai, Veithzal, Andria Permata Veithzal, Ferry N. Idroes. Bank and financial institution Management.Jakarta: Raja Grafindo Persada, 2007.

Sābiq, Sayyid. Fiqh al-Sunnah. Bairūt: Muassasah al-Rayyan, 2002.

Al-Zuhaili, Muhammad Muștafā alQawäid al-Fiqbiyah wa Tațbiqätuba fì al-Mażābib al-Arba'. Dimasyq: Dār al-Fikr, 1949 H.

Al-Zuhaili, Wahbah. Al-Fiqh al-Islami wa Adillatubu. Dimasq: Dar alFikr, $1433 \mathrm{H}$. 
Tarmizi, Erwandi. Harta Haram Muamalat Kontemporer. Bogor: PT. Berkat Mulia Insani, 2017.

Situs:

Ammi Nur Baits, ST., BA. Salah seorang dewan pembina konsultasi syariah pada situs konsultasisyariah.com , "about" https://konsultasisyariah.com/a bout (7 Januari 2019)

Asri, Lc., M.A. adalah Ketua Divisi Muamalat Dewan Syariah Wahdah Islamiyah Priode 20162021, Wahdah Islamiyah, "Susunan Pengurus Dewan Syariah Wabdab Islamiyah" http://wahdah.or.id/susunanpengurus-dewan-syariahwahdah-islamiyah/ (7 Januari 2019)

Bank Indonesia, Peraturan Bank. Indonesia Nomor No20/06/PBI/2018.

Dewan Fatwa Perhimpunan Al-Irsyad, Fatwa Haramnya Diskon yang didapatkan dari Go-pay dan Layanan yang sejenisnya Nomor 005/DFPA/VI/1439, Angka 4 dan 5

Dewan Syariah Nasional Majelis Ulama Indonesia, Fatwa Nomor 102/DSN-MUI/X/2016 tentang akad Al-Ijärah al-Mausufah fi alDrimmah Untuk Produk Pembiayaan Pemilikan Rumah (PPR)-Inden.

Dewan Syariah Wahdah Islamiyah, Resume Liqa' Ilmi 19 Dewan Syariah (Makassar: tp, 2018)

Dewan Syariah Wahdah Islamiyah, Resume Liqa' Ilmi 19 Dewan Syariah

Dewan Syariah Wahdah Islamiyah, Resume Liqa' Ilmi 19 Dewan Syariah

Dr. Erwandi Tarmizi Lc.,MA., penulis buku Harta Haram Muamalat
Kontemporer, Dosen tetap di program magister Ekonomi Syariah Sekolah Tinggi Ekonomi Islam Tazkia Bogor, Anggota Dewan Fatwa Perhimpunan Al-Irsyad, Pemateri fiqih kontenporer radio rodja, rodja TV bogor. ErwandiTarmizi "Me" https://erwanditarmizi.com/ab out/ (8 Januari 2019)

Dr. Oni Sahroni, MA, sebagai Direktur SEBI Islamic Business \& Economics Research Center (SIBER-C), Anggota Dewan Syariah Nasional (DSN) MUI, Tim Ahli Syariah ISRA - Bank Negara Malaysia, dan Anggota Dewan Standar Akuntansi Syariah (DSAS) IAI, http://www.rumahwasathia.org /rumahwasathia/biografi (7 Januari 2019)

Dzulqarnain bin Muhammad Sunusi sebagai pembina di Ma'had AsSunnah Makassar, Dzulqarnain "Biografi" http://dzulqarnain.net/biografi (8 Januari 2019)

Gojek Indonesia, "Kebijakan Privasi Gopay"Situs Resmi Gojek. https://www.go-jek.com/gopay/kebijakan-privasi/

Februari 2018).

Gojek Indonesia, "Kebijakan Privasi Gopay"Situs Resmi Gojek. https://www.go-jek.com/gopay/kebijakan-privasi/

Februari 2018).

Grab Indonesia, "Ketentuan layanan"Situs Resmi Grab. https://www.grab.com/id/term s/ (23Oktober 2018).

Grab Indonesia,"OVO dan Pembayaran" Situs Resmi Grab https://help.grab.com/hc/id/1 15001982507-OVO-dan- 
Website: https://journal.stiba.ac.id

ISSN : 2685-7537 (online) 2338-5251 (Printed)

Pembayaran?launch_path $=\mathrm{N} \% 2$ FA (23 Oktober 2018)

Islahuddin Mubarak, Lc.,M.H. adalah

Sekretaris Divisi Muamalat

Dewan Syariah Wahdah

Islamiyah Priode 2016-2021,

Wahdah Islamiyah, "Susunan

Pengurus Dewan Syariah Wabdah

Islamiyab"

http://wahdah.or.id/susunan-

pengurus-dewan-syariah-

wahdah-islamiyah/ (7 Januari

2019)

Islam Way "Fatwa mufașsalah fi alBitaqāt al-Madfūah musbiqa" https://ar.islamway.net/fatwa/3 4033 (8 Januari 2019).

Media Berdakwah, "Hukum Go Food dan Go Pay - Fadbilatul Ustadz. Drulqarnain $M$ Sunusi" https://www.youtube.com/wat ch?v=GJWvLr8poCk

Oktober 2018)

Ronny mahmuddin, Lc., M.A. adalah Ketua Divisi Ibadah Dewan Syariah Wahdah Islamiyah Priode 2016-2021, Wahdah Islamiyah, "Susunan Pengurus Dewan Syariab Wabdah Islamiyah" http://wahdah.or.id/susunanpengurus-dewan-syariahwahdah-islamiyah/ (7 Januari 2019)

Rumah Wasatia, "Tanya Jawab Fikih Muamalah No. 501 Hukum Top Up dalam Jasa Transportasi Online", Blagspot Rumah Wasatia http:/ / rumahwasatia.blogspot.c om/2017/10/tanya-jawab-fikihmuamalah-no-501-hukum.html (7 Januari 2019). 